\title{
THE NEVERENDING STORY OF AL HUSIN AND BOSNIA AND HERZEGOVINA: FROM EL-MUJAHEDIN TO FREEDOM?
}

\author{
UDC 341.44:314.745.3-054.74](497.6)
}

\section{Igor Popović, Olivera Ševo}

Faculty of Law, University of Banjaluka, Republic of Srpska, Bosnia and Herzegovina

\begin{abstract}
The paper deals with the problem which the authorities of Bosnia and Herzegovina face with regard to foreign combatants who participated in the BH civil war between 1992 and 1995. Many of them stayed in the country after the war, and authorities intend to deport some of them, who represent a threat to national security. One of them is Imad Al Husin, whose case best reflects the aforementioned problem. Since he has a citizenship of Syria, which cannot be considered a safe country regarding the nonrefoulement rule, process of deportation is facing difficulties. On the other hand, given the fact that he represents a threat to national security, he has been detained in an immigration centre for years. Since the authorities of Bosnia and Herzegovina cannot find a third safe country, the question arises on the lawfulness of the duration of his detention in the immigration centre. In that context, we analyzed the decision of the European Court of Human Rights and decisions of the Constitutional Court of Bosnia and Herzegovina regarding Imad Al Husin.
\end{abstract}

Key words: European Court of Human Rights, deportation, non-refoulement, detention, detention in view of pending deportation.

\section{INTRODUCTION AND CASE FACTS}

The case Al Husin v. Bosnia and Herzegovina ${ }^{1}$ has attracted significant public attention in Bosnia and Herzegovina (hereinafter: $\mathrm{BH}$ ). It illustrates the problem which $\mathrm{BH}$ is facing with foreigners who came to BH to fight during the civil war in the early 1990s. In most cases, these foreign combatants fought within paramilitary armed forces and stayed in $\mathrm{BH}$ after the war. Many of them obtained $\mathrm{BH}$ citizenship. Later, their citizenships were revoked, mostly because they had given false information and evidence at the time of

Received January $24^{\text {th }}, 2017$ / Accepted March $6^{\text {th }}, 2017$

Corresponding author: Igor Popović, LL.B.

Faculty of Law, University of Banjaluka, Bulevar vojvode Petra Bojovica 1A, 78000 Banja Luka, Republic of Srpska, Bosnia and Herzegovina

E-mail: i.popovic@pravobl.org

${ }^{1}$ Case Al Husin v. Bosnia and Herzegovina, Ap. 3727/08 
obtaining BH citizenship. Hence, BH authorities decided to deport many of them. The most famous one is Imad Al Husin.

Imad Al Husin (hereinafter: the Applicant), known in $\mathrm{BH}$ as $\mathrm{Abu} \mathrm{Hamza}^{2}$, is a Syrian national. He arrived to $\mathrm{BH}$ during the $\mathrm{BH}$ civil war between 1992 and $1995^{3}$, where he became member of the "El Mujahedi" unit that fought as part of the BH Army. After the war, the Applicant submitted a request for acquiring BH citizenship, which he obtained after two naturalisation decisions from different periods. In 2000, the Applicant was convicted for false_imprisonment of two local Serbs and imposed a suspended sentence of imprisonment.

Between 2001 and 2007, both rulings on naturalization were repealed by relevant $\mathrm{BH}$ authority on the grounds that the Applicant had acquired $\mathrm{BH}$ citizenship by means of fraudulent conduct, misrepresentation of information and concealment of relevant facts. From that moment, the Applicant's stay in BH became illegal. In order to acquire legal basis for his stay in $\mathrm{BH}$, he first applied for temporary residence but his application was rejected as he was considered a threat to national security. Then, the Applicant claimed asylum.

In his asylum application, he argued that the Syrian government considered him as a member of the (outlawed) Muslim Brotherhood; hence, he feared that, in case of his return to Syria, he might be exposed to torture and ill-treatment. He also alleged that the Syrian government was aware of his engagement in $\mathrm{BH}$, based on statements he gave to some TV stations, as a result of which members of his family were investigated by the police. He also stated that had avoided military service in Syria.

During his asylum procedure in $\mathrm{BH}$, the Applicant was placed in the Immigration Centre in Lukavac (hereinafter: Centre) since he allegedly represented a threat to national security, pursuant to Act on Movement and Stay of Aliens and Asylum ${ }^{4}$. The Applicant's detention was continuously extended. On many occasions, the applicant complained both on illegality of such measure and its duration, but his complaints were all rejected.

At the beginning of 2011, the BH authorities issued a deportation order. Thereafter, the applicant requested from the European Court of Human Rights (hereinafter: the Court, ECtHR) to provide a interim measure concerning State's treatment within the meaning of Article 3 of the European Convention for the Protection of Human Rights and Fundamental Freedoms (hereinafter: the Convention, ECHR), i.e. prohibition of the Applicant's deportation to Syria where there was a real risk of ill-treatment. In this case, the Court concluded that there would be violation of Article 3 if the person had to be deported to Syria, and that there was violation of Article 5 regarding detention before the decision on deportation was issued.

Several questions are of considerable importance for this case: first, the question of burden of proof of the potential ill-treatment in a third country; second, the assessment of general condition of human rights in a third country; and third, the question of applicability of certain sub-paragraphs of Article 5 (1) of the Convention. These issues will be discussed further on in this paper.

\footnotetext{
${ }^{2}$ The nickname Abu Hamza caused some problems to the Applicant given the fact that the famous terrorist Abu Hamza al-Masri used a similar nickname. Namely, the Applicant had been wrongly identified by the US authorities as Abu Hamza al-Masri, which caused further confusion in general public, media and among BH authorities. See: Hećimović, Esad (2009). Garibi - Mudžehedini u BIH. Beograd: Dan Graf - SEEMO, p. 26.

${ }^{3}$ During the 1980s, the Applicant studied in the Socialist Federal Republic of Yugoslavia; therefore, his arrival during the war was not his first stay in this part of Europe (Al Husin v. Bosnia and Herzegovina, Ap. 3727/08, § 16).

${ }^{4}$ The Act on Movement and Stay of Aliens and Asylum,Official Gazette of BH, nos. 36/08 and 87/12.
} 


\section{ApPliCABILITY OF ARTICLE 3 ECHR to AL HUSIN V. BoSNIA AND HERZEGOVINA}

\subsection{General remarks on indirect effect of Article 3 of the Convention}

When we think about prohibition of torture or some other action similar to torture, we have in mind the prohibition of the situation where an individual or a group of people beat up other person(s). It is considered a direct effect of Article 3 ECHR. It is a prohibition of direct actions performed by state agents which constitute ill-treatment. But, Al-Husin case deals with another kind of effect of Article 3 ECHR which can be considered indirect effect or extraterritorial effect ${ }^{5}$. It enables applicability of Article 3 ECHR not in situations where agents of a High Contracting Party perform ill-treatment themselves but rather in situations where the ill-treatment is likely to be performed by agents or individuals of some other state which the applicant is to be transferred to. The applicant's transfer may take effect in various circumstances, e.g. deportation, extradition. So, if an applicant is transferred to a territory of another state jurisdiction, he or she may be subject to ill-treatment.

Soering v. The United Kingdom was the first case where it was found that transfer from the High Contracting Party to another state would lead to violation of indirect effect of Article 3. In this case, the applicant was to be extradited to the USA for criminal trial. If he had been sentenced according to the US legislation, there would have been a real risk of being sentenced to death penalty. Bearing in mind that the period of waiting for the sentence to be imposed lasted from six to eight years on the average, the Court found that this period would have negatively affected the applicant, mainly his mental health. Therefore, the period of waiting, which is called death row phenomenon, would constitute ill-treatment which is explicitly forbidden by Article 3 ECHR.

Since then, in all cases regarding indirect effect of Article 3 ECHR, the Court has repeated the opinions from the Soering case and applied this rule not only in extradition cases but also in other similar cases, such as deportation cases. This approach is generally accepted in international human rights law, since the absolute prohibition of transfer of a person (refoulement) to a state where he/she could be ill-treated is considered to be ius cogens (Alston, Goodman 2013:446). Ratio legis of this prohibition is that a state cannot avoid its (moral) obligation by arguing that it will not torture a person and, therefore, it is not the state's concern what other state might do with that person. The Canadian judge C. Louis stated that "The ceremonial washing of his hands by Pontius Pilate did not relieve him of responsibility for the death sentence imposed by others" (Jayawickrama 2002:332).

For the Applicant, it is essential to prove the existence of substantial grounds for a real risk of ill-treatment in another state. According to the Court, the assessment of the existence of a real risk must be rigorous and the applicant is obliged to prove that he/she would probably be ill-treated, due to personal characteristics (e.g. being political opponent of the governing elite that uses oppressive means against the opposition) or due to generally bad situation in the state (e.g. high intensity war conflicts).

\subsection{Application of the Court's case-law in this case}

The Court applied its established practice when deciding about the applicability and merits of Article 3 ECHR. The Court first considered documents on the country situation

\footnotetext{
${ }^{5}$ Authors dealing with this issue have not come to agreement on the common term for this effect of Article 3 ECHR. For example, the term extraterritorial effect is used in White, Ovey 2010:179.
} 
where the Applicant was to be deported to. These documents come from international and national institutions ${ }^{6}$.

After that, the Court introduced its previously established principles and standards on indirect effect of Article $3 \mathrm{ECHR}^{7}$. The Court revoked that the right to "asylum is not contained in either the Convention or its Protocols" and found that Article 3 has "the absolute character no matter how undesirable or dangerous applicant might be" (§ 49). Further on, the Court reiterated that "the assessment of the existence of a real risk must be rigorous" ( $\$ 50)$ and it also refers to evidence and rules on the burden of proof. Regarding a burden of proof, the Court imposes an obligation upon the Applicant to adduce evidence about a real risk of ill-treatment. Where such evidence is adduced, it is for the Government to dispel any doubts about it.

\subsection{Factual background on human rights situation in Syria}

The relevant evidence of the human rights situation in Syria can be classified in the following way: 1) evidence on general treatment of persons deprived of liberty; 2) evidence on persons who did not respond to a call for military service; 3) evidence on particularly malicious treatment of members of the Muslim Brotherhood; and 4) evidence on general situation in Syria from the beginning of political crisis and political oppression.

The evidences accepted by the Court show that Syrian investigative authorities often ill-treat persons deprived of liberty, most often in order to get confessions or to collect evidence. Confessions gained in this way are usually accepted by Syrian courts, while complaints of ill-treatment rarely get examined ( $\S 40)$. The evidence belonging to the second group are contradictory in a certain way. Some reports state that persons do not get prison sentence despite avoiding obligatory military service. On the contrary, other reports cite that these persons can expect prison sentence for up to nine months ( $\$ 43$ ).

The reports also show specifically malicious treatment of the Muslim Brotherhood members who were exposed to particularly brutal ways of torture. Those who got convicted for membership in this organization were generally sentenced to death penalty and might be sentenced to twelve years in prison $(\S 41)$. Finally, evidence shows that from the beginning of political crisis in Syria the Government have acted very oppressively toward activists. Hence, the UK Home Office opinion from 2011 is that these persons should be approved asylum in the United Kingdom ( $\$ 42)$.

\subsection{Applicability of the Court's principles in the present case}

While applying general rules deriving from case-law to the facts of $A l H u s i n$ case, the Court found that national institutions did not fully consider the importance of the El Mujahedeen unit and consequences of membership in that organization. There is no doubt that the Applicant belonged to this unit, and that El Mujahedeen was related to the Al-Qaeda and similar organizations. The Applicant gave some interviews to TV stations in Arabic language where he clearly declared his membership in the El Mujahedeen unit

\footnotetext{
${ }^{6}$ In the Al Husin case, the documents come from the following institutions: the Committee Against Torture (\$ $38,40)$, the Commissioner of the Council of Europe for Human Rights ( $\$ 39)$, the United States Department of State (§ 40), Amnesty International (§ 41), Human Rights Watch (§ 41), UK Home Office (§ 42), Austrian Red Cross ( $\$ 43)$ and Danish Immigration Service ( $\$ 43)$.

${ }^{7}$ Al Husin v. Bosnia and Herzegovina, Ap. 3727/08, § 48-51.
} 
advocating extreme version of Islam. According to the Court, "these factors would be likely to make him a person of interest for the Syrian authorities" (§ 53). Finally, the Court claimed that the Applicant had submitted documents "indicating that he should be arrested upon the moment of his entering the country" (\$ 53) and that security services had a file with information about the Applicant. The State did not respond to these allegations but the Court kept silent on potential value of these documents. The Court concluded that, having in mind the state of human rights in Syria and the Applicant's status, there was a real risk that if deported to Syria, he would have been tortured.

Analyzing the Court's argumentation, we dare say with due respect that the explanation lacks sufficiently strong and clear evidences on possible ill-treatment, which in our opinion could have been corrected in at least four ways ${ }^{8}$.

Firstly, we find the qualification of the Applicant's membership questionable since, in the Court's judgement, it has not been qualified what would be particular state's interest towards the Applicant, and in which way he would be interesting for them. None of the reports mentioned members of the El Mujahedeen unit or related organizations being brutally tortured; the reported ill-treatments were applied only to members of the Muslim Brotherhood. Therefore, we can assume there was an "interest for ill-treating the applicant" since he would have been regarded as a member of the Muslim Brotherhood. Still, we consider that proper link between the El Mujahedeen unit and the Muslim Brotherhood in Syria is still missing. The Court could have done it through common co-founding of these organizations, their organizational hierarchy connection, the same goals, coordinated activities, etc. In such a way, the Court would have clearly explained why there was a real risk of the Applicant's ill-treatment in Syria.

Secondly, the legal explanation of the Court's standpoint could have been more acceptable if the Court had examined the Applicant's claims more thoroughly, in particular the ones on the interviews given by father and brother, and the documents of Syrian Government regarding the Applicant ( $\$ 23)$.

Thirdly, it could have been useful if the Court had examined the case of Muhammad Zammar who, according to the Applicant's claims, was tortured and sentenced in Syria to twelve years of imprisonment based on his membership in the Muslim Brotherhood, even though the evidence of his membership in this organization was lacking in trial. Since the evidence of the Applicant's membership was not submitted either, we believe that comparison of these two cases could have been useful.

Finally, bearing in mind that the situation in Syria at the time of the Court proceedings was far from the turmoil happening these days, we find that the Court could have examined more thoroughly not only the general conditions in Syria but also the particular situation in the regions or towns where the Applicant could have been deported to. It was possible that the Applicant would have been deported to the area where the armed conflict was not present or to the area of high intensity conflict ${ }^{9}$. It was also possible that the government did not use torture to combat the opposition in certain areas. That reasoning derives from the Court's case-law, since the Court found on many occasions that a person might be deported to a part of the country where there was no real risk of being ill-treated, even

\footnotetext{
${ }^{8}$ Some of the following problems and arguments were also raised in the dissenting opinion of Judge Mijović.

${ }^{9}$ In this regard, see Case Sufi and Elmi v. the United Kingdom, Ap. 8319/07 and 11449/07, in which the Court examined general protection of human rights in Mogadishu, the capital of Somalia, because it was the place where applicants were to be deported. The Court investigated possibilities of leaving airport in Mogadishu (as the place of arrival in Somalia) and departure to other potentially safer parts of Somalia or Kenya (\$ 265-296).
} 
though such risk might exists in other parts of the country (Harris, O'Boyle, Bates, Buckley, Harvey, Lafferty, Cumper, Arai, Green, 2014:251).

Therefore, we are of the opinion that from the procedural point of view the Court could have paid more attention to the factual background of the case and its evaluation. It surely does not mean that the result should have been different. The reasoning in the Court judgment would have been of a more significant impact.

\section{ApplicAtion of ARTiCle 5 ECHR to Al Husin V. BosNia AND HERZEGOVINA}

\subsection{General remarks on Article 5 of the Convention}

The Convention protects the right to freedom and security of person as inalienable rights. Naturally, the major characteristic of this article is the question of detention (deprivation of liberty). Namely, even though High Contracting Parties of the Convention are obliged to respect freedom of personality, there are various cases that justify the deprivation of liberty. That being said, limitation of freedom of liberty is clearly and precisely defined by the Convention. What is inseparable from both the Convention as a whole and Article 5 in particular is its further elaboration through the Court's case-law. It defines the notion of "detention", legality of detention, but also unlawful detention compensation. Here, it is important to emphasize that Article 5 ECHR expressly requires that the detention procedure shall be conducted in accordance with the law, both in substantive sense (in terms of legal bases for detention) as well as in procedural sense (the entire deprivation of liberty procedure). Violation of the Article 5 ECHR can also occur even when all the substantive and procedural provisions of relevant national legislation are respected, if such provisions are not in accordance with the Convention.

The Court has not elaborated whether detention happened in the actual case or not. Namely, based upon the landmark cases regarding Article 5 of the Convention, it is clear that conditions listed in the Convention have been respected. While arguing whether certain measure represented detention, in the Engel v. Netherlands case, the Court concluded that "whole range of factors such as the nature, duration, effects and manner of execution of the penalty or measure in question" ${ }^{10}$ must be taken into account. We assume that the Court has taken into account the meaning of detention, its duration, and security measures in the Centre, and so on. That is why the Court found that all the detention criteria were met.

Yet, what is definitely debatable was the legal ground of the Applicant's deprivation of liberty. He was deprived of liberty because he "represented threat to national security",11. This paper will discuss whether this was legally sufficient and, if so, to what extent. We find proper to question under which sub-paragraph of the Article 5(1) the eventual violation should be assessed.

\subsection{Article 5 (1) c) of the Convention}

Even though Article 5 prescribes several grounds for lawful deprivation of liberty, this paper focuses on Article 5(1) sub-paragraphs c) and f).

Sub-paragraph c) refers to deprivation of liberty with purpose of bringing the person before the competent legal authority in order to prevent committing the offence when

\footnotetext{
${ }^{10}$ Case Engel and others v. The Netherlands, Ap. 5100/71; 5101/71; 5102/71; 5354/72; 5370/72, § 59.

${ }^{11}$ Al Husin v. Bosnia and Herzegovina, Ap. 3727/08, § 28.
} 
there exists any doubt that such act could be done ${ }^{12}$. What is exceptionally important for the concrete case is the aim of the deprivation of liberty. Namely, sub-paragraph c) requires that the aim of deprivation of liberty needs to be bringing the person before the competent legal authority. That also means that the person deprived of liberty has the right to be promptly brought before the competent judicial authority. Starting from the case Lawless $v$. Ireland ${ }^{13}$, the Court's case-law clearly requires that deprivation of liberty can be justified solely if there is an intention or aim that the person is brought before the competent legal authority, in case of suspicion that he/she might commit the offence. Therefore, detention of the person without a clear aim to be processed causes the violation of Article 5 ECHR.

Also, concretization of the offence is an important issue regarding deprivation of liberty. It means that in case of deprivation of liberty the real cause cannot be "general prevention" The Court's case-law clearly shows that the legal basis for detention cannot be preservation of national security or any other general measure. On the contrary, in order to legally deprive an individual of the right to liberty, there has to be a reasonable suspicion that the concrete offence might be committed. Therefore, in the case A. and Others $v$. the United Kingdom, the Court stated that it "does not accept the Government's argument that Article 5 \& 1 permits a balance to be struck between the individual's right to liberty and the State's interest in protecting its population from terrorist threat. This argument is inconsistent not only with the Court's jurisprudence under sub-paragraph (f) but also with the principle that subparagraphs $(a)$ to $(f)$ amount to an exhaustive list of exceptions, and that only a narrow interpretation of these exceptions is compatible with the aims of Article 5,15.

\subsection{Article 5 (1) f) of the Convention}

Sub-paragraph f) concerns lawful deprivation of person's liberty in order to prevent his/her illegal entry in the country, or lawful deprivation of liberty of a person involved in current process of extradition or deportation. It is important for the deprivation of liberty to be in accordance with national legislation and not to be imposed for any other purpose but for carrying out deportation or extradition. Accordingly, for the person to be deprived of liberty in accordance with sub-paragraph $\mathrm{f}$ ), there must be a link to the deportation, but it is not necessary to suspect whether the person will commit the offence or fleeing after having done so (Duterte, 2002:108). The lawfulness of detention and the lawfulness of extradition shall not be confused here (Macovei, 2002:38). In this respect, sub-paragraph f) deals only with the lawfulness of detention.

\subsection{Application of the Article 5 of the Convention in Al Husin v. Bosnia and Herzegovina}

In the concrete case, there is dilemma about applicability of sub-paragraphs $c$ ) and/or f). While considering merits regarding Article 5, the Court has actually examined the case in light of both sub-paragraphs ${ }^{16}$. The dissenting opinion of judge Lj. Mijović pointed out to difficulties related to this issue.

\footnotetext{
${ }^{12}$ Also, this point concerns deprivation of liberty in case when there is reasonable doubt that the person has comitted an offence or he/she will escape after having comitted the offence.

${ }^{13}$ Case Lawless v. Ireland. Ap. 332/57, Lawless v. Ireland, \$ 14.

${ }^{14}$ With the exception of Article 5 (1) sub-paragraph $e$ ).

${ }^{15}$ Case A. and others $v$. The United Kingdom, Ap. 3455/05, § 171.

${ }^{16}$ According to the Court's case-law it is possible to examine one case within the two or more sub-paragraphs. See Case Ap. 17391/90, Eriksen v. Norway, § 76.
} 
When analyzing the sub-paragraph c), we would have to recall reasons for deprivation of liberty in this case. The Court requires, as said above, that national authorities can detain a person on a reasonable suspicion that he/she has committed or will commit an offence existing under national law. The concrete case does not clearly define what kind of criminal offence it was. Simply, the BH authorities had to to specify the criminal offence, which they did not do but used a broad description ("threat to national security") instead. One can only guess that such a criminal offence was linked to terrorism. Nonetheless, at the moment of deprivation of liberty, the Applicant was not properly informed which criminal offence he was charged with, nor did the Government offer any explanation to the Court. Any kind of measure aimed at general prevention does not permit exceptions under sub-paragraph c). The Applicant was detained according to the Act on Movement and Stay of Aliens and Asylum, which actually enabled the detention, but such general prevention was contrary to the Court's case-law.

Sub-paragraph c) sets another requirement on bringing the deprived person before the competent legal authority. Therefore, the aim of arrest needs to be bringing the person before judge or another competent authority. In the concrete case, the criminal offence was not specified, nor was the Applicant brought before a judge or another competent authority. Instead, the authorities placed the Applicant in the Centre and kept extending his detention according to the Act on Movement and Stay of Aliens and Asylum. From all the above, analyzing this case under Article 5(1) c), we definitely could not treat this case as the legal exception from prohibition of deprivation of liberty, and it is clear why in the respective situation there has been violation of Article 5(1).

On the other hand, it is possible to consider the respective case in the context of subparagraph f). Since the case considers a person in the deportation process from $\mathrm{BH}$, we may pose the question whether his detention can be justified on the basis of subparagraph $\mathrm{f}$ ). In this case, the time when the process of deportation began was of crucial importance. The Applicant was placed in the Centre after the Aliens Service had brought the decision of the matter. At the moment when the Applicant was placed in the Centre, there was no ruling about deportation, i.e. such process had not formally begun. On the other hand, one year before the detention, the Applicant was given a period during which he could have left the country voluntarily. Could this be related to the process of deportation? In other terms, could the proceedings that preceded the ruling on deportation, made two and a half years after the Applicant's detention, have been seen as deportation in a broad sense of sub-paragraph f)? The period of detention related to the moment of ruling on deportation is not disputable and represents a lawful exception ${ }^{17}$.

Given the fact that two and a half years had passed between the Applicant's detention and the final decision on deportation, we believe that the link between his detention and the deportation process was missing. During this period, $\mathrm{BH}$ authorities had only dealt with the Applicant's asylum request and no other deportation action had been taken. Additionally, according to accessible information, the aim of the Applicant's detention in the Centre was to preserve national security, despite the legal character of this institution. According to the same sources, the $\mathrm{BH}$ authorities did not link detention to deportation either during the Applicant's detention or during its prolongation, but exclusively to the issue of preserving national security, which would certainly refer to application of subparagraph c) in this case ${ }^{18}$.

\footnotetext{
${ }^{17}$ Al Husin, § 69 .

${ }^{18}$ This is one of the reasons why judge $\mathrm{Lj}$. Mijović delivered her dissenting opinion.
} 


\section{THE AFTERMATH OF AL HUSIN V. BOSNIA AND HERZEGOVINA}

The result of the Court's decision was that the Applicant was never deported to Syria but kept in the Centre. BH tried to deport him to other countries, but without success (as 39 countries refused to accept the Applicant) ${ }^{19}$. Hence, no safe third country was found where he could be deported. As the $\mathrm{BH}$ authorities still considered the Applicant to be a threat for the national security, in accordance with the Act on Movement and Stay of Aliens and Asylum, they periodically kept prolonging his detention in Centre until February 2016. He was released from the Centre with the obligation to report periodically to the authorities ${ }^{20}$.

During his stay in the Centre, the Applicant filed several appeals to the Constitutional Court of Bosnia and Herzegovina (hereinafter: $\mathrm{CCBH}$ ) complaining about the violation of his human rights. The appeals were mainly based upon the decision of the Aliens Service and the Ministry of Security of $\mathrm{BH}$, and the Court of $\mathrm{BH}$, which violated the rights guaranteed by the Article 5(1) f) of the Convention. The two last rulings on appeal were issued on 17 June 2015 and on 22 December 2015 by CCBH. The former partly upheld the appeal, and the latter rejected the appeal as ill-founded ${ }^{21}$.

In the CCBH decision of 22 December 2015, no violation of the Applicant's human rights was found since the whole procedure prescribed by the Act on Movement and Stay of Aliens and Asylum and the procedural guarantees from the Convention had been respected. It is especially important to emphasise that courts and administrative bodies have periodically examined the basis for detention and decided to extend its duration. In this way, they were regularly controlling fulfilment of requirements for detention in the Centre.

The $\mathrm{CCBH}$ found that there was a violation of Article 5(1) f) by the fact that during the decision-making by administrative bodies and the Court of BH, in the period from 14 March 2013 to 6 January 2014, "the Appellant was not familiar with the content of information provided by the ISA ${ }^{22}$, based on which he was marked as a person representing a threat to national security, nor did the Court of $\mathrm{BH}$ adequately rate the stated information and plead on their merits ${ }^{, 23}$. The CCBH referred to its previous reasoning in a similar case, where the procedure before the Court of $\mathrm{BH}$ in an administrative dispute regarding the decision of Ministry of Security of BH and the Aliens Service about detention in the Centre had not met the standard of lawfulness required by Article 5 ECHR, because "the appellant was deprived of liberty since he represented a threat to national security, based upon information provided by the ISA that was not indicated to him in any manner, while it was not possible to conclude from the reasons and justification of the disputed decisions that the Court of $\mathrm{BH}$, according to its legal authority, rated adequately this statement and pleaded on its merits "24.

According to the $\mathrm{CCBH}$, the standard of lawfulness of deprivation of liberty in the context of Article 5(1) f) of the Convention is met: (1) if the person has at least received indications about evidence proving him/her to be a threat to national security, and (2) if the Court of $\mathrm{BH}$ in its decision clearly states and explains that such evidence were

\footnotetext{
${ }^{19}$ Constitutional Court of Bosnia and Herzegovina (CCBH), Case Ap. 2832/15, $\S 8$.

${ }^{20}$ Media covered this event. For example, see the newspaper article: "Imad Al Husin released", Al Jazeera Online, Retrieved on 22 November 2016, from http://balkans.aljazeera.net/vijesti/imad-al-husin-pusten-na-slobodu.

${ }^{21}$ CCBH, Case Ap. 2832/15.

${ }^{22}$ Full title: "Intelligence - Security Agency of Bosnia and Herzegovina".

${ }^{23} \mathrm{CCBH}$, Case Ap.2742/13, § 48.

${ }^{24} \mathrm{CCBH}$, Case Ap. 4064/13, § 66. (Highlighted by authors)
} 
examined, in compliance with the Secret Data Act, ${ }^{25}$ whereby the decision proves that information provided by the examined evidence is well-founded at least prima faciae. This second condition basically refers to work of the judiciary that should be highly diligent. It also specifies that courts need to examine lawfulness of deprivation of liberty thoroughly. However, given the high sensitivity of the case at issue, the prima faciae evidence that the Court referred to needs to be convincing that the deprivation of liberty is well-founded. Hence, it shall be determined in each case whether this lower standard of proof shall apply. Unfortunately, the $\mathrm{CCBH}$ did not offer a more complete criterion or test that could help to assess the fulfilment of the aforementioned conditions.

The unlawfulness standard was later corrected by further decisions of the Court of BH. First of all, the Court of the BH overruled part of previous decisions about extending the detention in the Centre, pointing out that the Appellant was unable to examine ISA's evidences about being an alleged threat to national security ${ }^{26}$. After that, some pieces of evidence (despite being marked as secret ones) were presented to the Appellant, who referred to them in his appeal ( $\$ 55)$. But, such process led to the same conclusion - that the detention was lawful.

Finally, the Court of $\mathrm{BH}$ held that the period of detention in the Centre was not crucial for reviewing the lawfulness of the Applicant's detention ( $\$ 54)$. The CCBH referred to the Court's case-law, especially the case Chahal ( $\$ 51)$, where the applicant was detained over 6 years based upon the same sub-paragraph f) Accordingly, the period of seven years, during which the Appellant had been detained in the Centre at the moment of delivering the aforementioned decisions by the $\mathrm{CCBH}$, did not affect the lawfulness of detention in the Centre.

We may wonder why the Applicant was released after all. Did he stop being a threat? Certainly not! Officially, BH authorities still consider him a threat to the national security ${ }^{27}$. The Applicant owes his release to the new Aliens Act $(2015)^{28}$, which prescribes that continuous detention of aliens in an immigration centre cannot exceed 18 months (Art. $119(6))$.

Thus, the Applicant's detention finally came to an end. Yet, the legal drama of this case is far from being over since the Applicant has publicly announced his intention to sue $\mathrm{BH}$ for his unlawful deprivation of liberty. In reaction to his notice, the $\mathrm{BH}$ authorities claim that they still consider him a threat to national security and will pursue all possible ways to deport him ${ }^{29}$.

\footnotetext{
${ }^{25}$ Act on the Protection of Secret Data, Official Gazette of BH, nos. 54/05 and 12/09. According to Article. 5(1) c) of this Act, the Court of $\mathrm{BH}$ and $\mathrm{CCBH}$ judges have access to secret data of all levels without security control, i.e. without obtaining permission to access secret data.

${ }^{26} \mathrm{CCBH}$, Case Ap. 2742/13, § 56.

${ }^{27}$ The Minister of Security of BH clearly stated: "For us, Al Husin still represents a threat to national security of Bosnia and Herzegovina"; cited after "Imad al-Husin released", Al Jazeera Online. See also the announcement posted on the Aliens Service website: "Syrian citizen released from Immigration Centre", Retrieved on 23 November 2016, from http://sps.gov.ba/saopstenja/test-post.

${ }^{28}$ Aliens Act, Official Gazette of BH, no. 88/15.

${ }^{29}$ Current Minister of Security of $\mathrm{BH}$ asserts: "We will still work hard to deport him from Bosnia and Herzegovina"; Cited after "Imad al-Husin released", Al Jazeera Online.
} 


\section{CONCLUSION}

This analysis of the Applicant's cases brought before the ECtHR and later before the $\mathrm{CCBH}$ points out to the necessity of striking the proper balance between the rights of an individual and the protection of national security. The easiest solution for the state could be deportation of an individual to a third country, following the proverb: a problem shared is a problem halved. Yet, this possibility is less probable due to the absolute ius cogens provision on deportation prohibition to the countries where the deported person may be tortured or ill-treated.

Such person can be deprived of liberty by the authorities of a High Contracting Party in accordance with Article 5(1) f) ECHR. Still, as we have seen, such deprivation always has to be in the service of deportation; it cannot exist separately as some general precaution measure. For this reason it is crucial for judicial review to be done periodically, in terms of examining the merits and lawfulness of detention in case of pending deportation when deportation to a third country is not (yet) possible. It seems that courts in $\mathrm{BH}$ have worked rather zealously. Based on the opinions of $\mathrm{CCBH}$, we can conclude that such periodical examination is among crucial reasons why the Applicant's habeas corpus was strictly respected.

In terms of the detention period, the Court and $\mathrm{CCBH}$ find that the Article (1) f) does not define the upper limit of duration of detention in immigration centres pending deportation. But, as the final aim is deportation, deprivation of liberty will be in accordance with the Convention as long as there is a "deportation process", i.e. until state takes measures necessary for deportation, e.g. seeks for third safe countries that would receive the person (Mcbride, 2005:47).

The changes introduced by the new Aliens Act concern the detention in the Centre which cannot last more than 18 months continuously ${ }^{30}$. Thus, the Applicant has been set free but his deportation is still in progress and his movement is limited within the territory of the Canton of Sarajevo. If he does not respect those limitations, he can be put back in the Immigration Centre.

Except for detention in sense of Article 5(1) f) of the Convention, the second probability is criminal prosecution. According to Article $202 \mathrm{~d}$ of the Criminal Code of $\mathrm{BH}^{31}$, it is possible to punish a person even for membership to a certain terrorist group, where the terrorist group is defined as "organized group including at least three persons, which is formed and works in a certain period of time with the aim to commit criminal acts of terrorism". In this case, the available evidence does not establish why the Applicant is considered a threat to national security, but we can assume that his past activities linked him to certain terrorist groups. If that proves to be correct and if the required evidence are obtained lawfully, then the prosecuting authority can argue that the Applicant has committed the aforementioned criminal offence. Hence, this option depends only on the strength of evidence possessed by the State, upon which it considers an individual to be a threat to national security.

\footnotetext{
${ }^{30}$ Such legislation was adopted in order to harmonize legislation of BIH with EU Directive on common standards and procedures in Member States for returning illegally staying third-country nationals 2008/115/EC. ${ }^{31}$ Criminal Code of BH, Official Gazette of BH, no. 3/03, 32/03, 37/03, 54/04, 61/04, 30/05, 53/06, 55/06, $32 / 07,8 / 10,47 / 14,22 / 15$ i 40/15.
} 
All things considered, it could be said that the problem of foreign combatants in $\mathrm{BH}$ has not been solved yet. The national authorities have been shifting the responsibility from one body to another, without a genuine intention to systematically deal with the problem (Mijović, 2014:64). Unfortunately, although different from the earlier one, the new legislation does not offer a definite solution of this problem.

\section{REFERENCES}

Alston, P., Goodman R. (2013). International Human Rights, Oxford University Press, Oxford.

Duterte, G., (2002). Izvodi iz sudske prakse - Evropski sud za ljudska prava (Case law excerpts - European Court of Human Rights), Savjet Evrope - Studis d.o.o, Sarajevo.

Harris, D., O’Boyle, M., Bates, E., Buckley, C., Harvey, P., Lafferty, M., Cumper, P., Arai, Y., Green, H., (2014). Law of the European Convention on Human Rights, Oxford University Press, Oxford.

Macovei, M., (2002). The right to liberty and security of the person, Council of Europe, Strasbourg.

Mcbride, J., (2005). Pravo na slobodu i sigurnost ličnosti (Right to liberty and security), Savjet Evrope, Sarajevo.

Mijović, Lj., (2014). Bosna i Hercegovina pred Evropskim sudom za ljudska prava (Bosnia and Herzegovina before the European Court of Human Rights), Comesgrafika d.o.o., Banja Luka.

Jayawickrama N., (2002). The Judicial Application of Human Rights Law: National, Regional and International Jurisprudence, Cambridge University Press, Cambridge.

White, R. C. A., Ovey, C., (2010). Jacobs, White \& Ovey: The European Convention on Human Rights, Oxford University Press, Oxford.

"Državljanin Sirije pušten iz imigracionog centra", Retrieved on 23 November 2016, from http://sps.gov.ba/ saopstenja/test-post.

"Imad Al Husin pušten na slobodu", Al Jazeera Online, Retrieved on 22 November 2016, from http://balkans. aljazeera.net/vijesti/imad-al-husin-pusten-na-slobodu

\section{Legislation}

Krivični zakon Bosne i Hercegovine (Criminal Code of Bosnia and Herzegovina), Službeni glasnik BiH br. 3/03, 32/03, 37/03, 54/04, 61/04, 30/05, 53/06, 55/06, 32/07, 8/10, 47/14, 22/15 i 40/15)

Zakon o kretanju i boravku stranaca i azilu Bosne i Hercegovine (Act on Movement and Stay of Aliens and Asylum), Službeni glasnik Bosne i Hercegovine br. 36/08 i 87/12)

Zakon o strancima (Aliens Act), Službeni glasnik Bosne i Hercegovine br. 88/15)

Zakon o zaštiti tajnih podataka (Act on Protection of Secret Data), Službeni glasnik BiH br. 54/05 i12/09)

\section{Case Law}

Case Al Husin v. Bosnia and Herzegovina, Ap. 3727/08

Case A. and others v. the United Kingdom, Ap. 3455/05

Case Engel and others $v$. the Netherlands, Ap. 5100/71; 5101/71; 5102/71; 5354/72; 5370/72

Case Eriksen v. Norway, Ap. 17391/90

Case Lawless v. Ireland, Ap. 332/57

Case Sufi and Elmi v. the United Kingdom, Ap. 8319/07 and 11449/07

CCBH, Case Ap. 2742/13.

CCBH, Case Ap. 2832/15

CCBH, Case Ap. 4064/13. 


\section{PRIČA BEZ KRAJA O AL HUSINU I BOSNI I HERCEGOVINI: OD MUDŽAHEDINA DO SLOBODE?}

Članak se bavi problemom sa kojim se vlasti Bosne i Herzegovine susreću u pogledu boravka $i$ deportacije stranaca koji su došli u državu da se bore tokom građanskog rata i ostali u njoj nakon rata. Neke od njih vlasti žele da deportuju, jer im je oduzeto državljanstvo i predstavljaju prijetnju po nacionalnu sigurnost. Jedan od njih je i Imad Al Husin čiji slučaj najbolje oslikava pomenuti problem. Obizrom da on dolazi iz države Sirije koje se ne smatra sigurnom u smislu pravila non-refoulment, deportacija je otežana. S druge strane, on je lišen slobode i pritvoren u imigracionom centru, zato što predstavlja opasnost po nacionalu sigurnost. Postavlja se pitanje opravdanosti dužine pritvora, $s$ obzirom da vlasti BiH ne mogu da pronađu treću sigurnu državu u koju bi se deportovao stranac. U tom smislu analziramo odluku Evropskog suda za ljudska prava u predmetu Al Husin protiv Bosne $i$ Herzegovine, kao i odluke Ustavnog suda BiH u odnosu na aplikanta.

Ključne reči: Evropski sud za ljudska prava, deportacija, non-refoulment, lišavanje slobode, lišenje slobode u toku postupka deportacije. 